\title{
RITUAL ALO PADA MASYARAKAT CIA-CIA BURANGASI KABUPATEN BUTON
}

\author{
La Janu \\ FKIP Universitas Haluoleo \\ Jl. H.E.A. Mokodompit, Kendari. Telp. 081227877675 \\ email: lajanu@yahoo.com
}

\begin{abstract}
This research examined alo ritual in Cia-Cia community Burangasi Buton, South East Celebes Province. This research is conducted to identify answers for the concerning problems described of its present the importance of alo ritual in even the whole community. This study used a qualitative research method with participal observation and in depth interview as data collecting method. While data analysis, was done through ethnographic analysis technique. Alo ritual was carried out by reason of mental pressure or mental crisis caused by the death in family member. They concern about safety of spirit of the death given that the spirit has to experience a long and dangerous passage. They believe that this spiritually dangerous crisis time is not about the death only but covering up the whole family and even the whole community. In general, alo ritual had a purpose to normalize the unstable life condition of the family because of a death through deconstructing the existing life condition and reconstructing it into the brand new one at the same time. In such condition of brand new life, daily activities seem harmonious and normal without any fears, distress, depressed and so on.
\end{abstract}

Penelitian ini fokus pada upacara alo yang terjadi di masyarakat Cia-Cia Burangasi Buton, Propinsi Celebes Tenggara. Penelitian ini dilakukan untuk mengidentifikasi jawaban-jawaban atas problematika penting terkait upacara alo dalam sebuah komunitas. Kajian ini menggunakan metode kualitatif dengan observasi partisipatoris dan wawancara mendalam sebagai teknik pengumpulan data. Data yang telah terkumpul kemudian dianalisa dengan teknik analisis etnografi. Upacara alo dilakukan dengan alasan ketertekanan jiwa dan krisis mental yang disebabkan karena kematian salah satu anggota keluarganya. Mereka berkonsentrasi terhadap keselamatan arwah dari sang mayat yang 
akan melalui lintasan panjang berbahaya. Mereka berkeyakinan bahwa saatsaat yang membahayakan bagi arwah ini tidak hanya menimpa si mayat saja, melainkan juga seluruh anggota keluarga bahkan seluruh masyarakat. Secara umum, upacara alo bertujuan untuk menormalkan keadaan hidup yang tidak stabil akibat kematian si mayat. Dalam keadaan hidup yang baru ini, kegiatan sehari-hari nampak harmoni dan stabil tanpa ketakutan, penderitaan, tekanan, dan seterusnya.

Key words: ritual alo, significance

\section{Pendahuluan}

Eksistensi kehidupan manusia di dunia ini, merupakan suatu proses yang diawali oleh peristiwa kelahiran dan akan berujung pada kematian. Tentunya, sebelum sampai pada kematian, manusia senantiasa melalui berbagai fase dalam hidupnya. Proses inisiasi atau peralihan dari fase kehidupan yang satu ke fase kehidupan yang lain, melahirkan sejumlah implikasi psikologis religius dan sosial berupa krisis mental, yang disebabkan adanya perubahan-perubahan sikap, perilaku dan peran-peran yang dilakukan seseorang dalam melalui masa tersebut. Dalam upaya menormalisasikan atau menstabilkan berbagai krisis tersebut, biasanya dilakukan melalui institusi ritual yang berhubungan dengan masa peralihan tersebut.

Ritual yang mengiringi setiap perubahan atau mengitari tahapan hidup manusia, oleh Van Gennep disebut "rites de passage", atau Turner menyebutnya "the rites of passages" (Koentjaraningrat, 1980: 75). Tahapan-tahapan tersebut terjadi sejak ia lahir, kemudian menjadi masa kanak-kanak, pendewasaan dan menikah, menjadi orang tua, hingga saatnya ia meninggal, manusia mengalami perubahan-perubahan biologi serta perubahan dalam lingkungan sosial budayanya yang dapat mempengaruhi jiwanya dan menimbulkan krisis mental. Dalam kaitannya dengan ritual kematian, Van Gennep membagi semua ritus dan upacara itu ke dalam tiga bagian, yaitu perpisahan atau separation, peralihan atau marge (liminal), dan integrasi kembali atau agregation (Winangu, 1990: 35).

Dalam kaitannya dengan kematian, masyarakat Cia-Cia Burangasi, Kabupaten Buton, mengenal jenis ritual yang disebut dengan alo. Ritual ini dilaksanakan sesudah kematian anggota kerabat, yakni pada hari ketiga (tolu alono), hari ketujuh (picu alono), hari keempat puluh (pato pulu alono), hingga hari yang keseratus (ahacu alono). Ritual tersebut telah mendarahdaging dalam kehidupan masyarakat pendukungnya, karena diyakini masih fungsional dan 
memiliki sejumlah makna yang berarti bagi kehidupannya, sehingga tidak melaksanakannya berarti telah melakukan pelanggaran baik secara religius maupun secara sosial. Oleh karena itu, jika ada anggota keluarga mereka yang meninggal dunia, mutlak menyelenggarakan ritual "alo".

Ritual ini melibatkan hampir seluruh karib kerabat, teman, seprofesi, maupun karena ikatan emosional lain dengan orang yang diritualkan atau keluarganya. Penyelenggaraan ritual tersebut menghabiskan biaya, waktu dan tenaga yang relatif besar, tidak kurang dari satu hingga empat ekor kambing dikurbankan untuk bahan sesaji dan beberapa ekor ayam harus dipotong untuk dikonsumsi, belum lagi pengorbanan materi yang berkaitan dengan akomodasi pelaksana teknis dan konsumsi peserta secara keseluruhan, meskipun membutuhkan pengorbanan yang besar, ritual tersebut terus dipertahankan oleh masyarakat pendukungnya. Secara hipotetis ada makna-makna yang tersimpan di dalamnya. Secara antropologis makna-makna itu perlu digali dan dipahami untuk memperoleh pengetahuan tentang kebudayaan masyarakat yang bersangkutan.

Bertolak dari pandangan para ahli serta hasil studi terdahulu di atas, maka perihal yang paling mendasar sehubungan dengan penelitian ini adalah bagaimana makna ritual tersebut bagi masyarakat pendukungnya. Berhubung cakupan masalahnya terlalu luas, maka tulisan ini secara spesifik menganalisis makna ritual tersebut dari sisi operasional, berdasarkan tiga tahapan menurut para ahli di atas.

\section{Metode Penelitian}

Penelitian ini dilaksanakan pada masyarakat Cia-Cia Burangasi, Kabupaten Buton, Provinsi Sulawesi Tenggara. Pengumpulan data di lapangan menggunakan teknik participant observation (Spradley,1997: 106) dan indepth interview (Bungin, 2007: 108). Informan kunci (key informants) dalam penelitian ini adalah tokoh agama (imam) setempat yang senantiasa bertindak sebagai pemimpin ritual secara turun temurun dan diasumsikan paling mengetahui hal ikhwal ritual alo. Informan lain ditentukan secara snowballing menurut informasi dari informan kunci. Dengan teknik snowballing, maka jumlah informan tidak terbatas jumlahnya. Data dalam penelitian ini dianalisis secara deskriptif kualitatif.

\section{Hasil dan Pembahasan}

Menurut pandangan beberapa ahli antropologi, ritual merupakan 
salah satu bentuk drama sosial yang menampilkan peran-peran simbolik. Melalui drama sosial itu, berbagai segi kehidupan masyarakat dipertunjukkan untuk ditanggapi bersama (Turner, 1987: 32-33). Secara spesifik di dalam ritual peralihan atau the rites of passages terjadi proses pengolahan batin yang menyebabkan manusia mampu keluar dari berbagai konflik akibat adanya perubahan-perubahan yang dihadapi manusia dalam hidupnya (Turner, 1982: 94). Turner membagi proses itu dalam tiga tahapan, yakni tahap pemisahan atau separation, tahap liminalitas, dan tahap pengintegrasian kembali (reaggregation) (Turner, 1982: 94). Melalui ketiga tahapan itu terjadi proses pembentukan diri atau formatif secara psikologis sehingga si subyek ritual diteguhkan dan memiliki orientasi hidup yang baru.

Proses ketiga tahapan tersebut berlangsung sejak peristiwa kematian hingga diselenggarakannya ritual alo, yaitu dimulai dari hari ketiga sesudah kematian (tolu alono), hari ketujuh (picu alono), hari keempat puluh (pato puluno) dan berakhir pada hari yang keseratus (ahacu alono) sebagai ritual pelepasan atau penghabisan (polapasia atau kapolapasia). Unsur-unsur simbolik yang mengindikasikan tahap pemisahan atau separation antara lain, bendera putih, pantangan dan suasana hening. Turner mengistilahkan unsur-unsur simbolis ini sebagai simbol-simbol anti struktur, yang melahirkan kondisi hidup yang berbeda dari suasana hidup normal pada umumnya. Tahap liminalitas berlangsung selama masa perkabungan yakni antara peristiwa kematian hingga saat pelaksanaan ritual alo, sedangkan tahap pengintegrasian kembali atau reaggregation terjadi ketika ritual alo secara keseluruhan dilaksanakan. Berikut ini akan dikemukakan ciri dan bentuk ketiga tahapan proses peralihan tersebut.

\section{Tahap Pemisahan atau separation.}

Ketika seseorang menghembuskan nafas yang terakhir, maka salah seorang anggota keluarganya memasang bendera putih. Hal ini dimaksudkan bahwa di areal rumah tersebut tidak diperkenankan untuk melakukan berbagai kegiatan yang bersifat gaduh karena adanya peristiwa kematian. Menurut para informan, selama masa perkabungan tersebut roh orang yang meninggal dunia masih berada bersama sanak keluarganya karena itu suasana tenang perlu dijaga dengan sebaik-baiknya.

Semua jenis aktivitas yang dapat menimbulkan gangguan seperti teriakan, tawa, makian, tangisan, nyanyian, musik dan sejenisnya tidak boleh dilakukan selama masa perkabungan ini. Demikian pula kegiatan mencari nafkah untuk 
pemenuhan kebutuhan hidup sehari-hari seperti melaut, membuka lahan perkebunan, berburu, pergi merantau dan sebagainya, selama masa perkabungan tidak diperbolehkan karena mengandung ancaman-ancaman gaib. Beraktivitas pada kurung waktu tersebut diyakini hanya akan mendatangkan malapetaka dan kegagalan (sial) bagi pelakunya. Kondisi kehidupan mereka benar-benar menjadi berubah dari hari-hari sebelumnya. Suasana saat ini nampak tenang walaupun kadang suara tangisan tidak dapat terhindarkan terutama dari anggota keluarga yang ditinggalkan karena tidak kuasa menahan kesedihannya. Umumnya tangisan tersebut banyak terjadi pada kaum wanita. Keheningan dan ketenangan ini berlangsung hingga diadakan pelepasan simbol-simbol duka yakni antara 1 hingga 2 hari sebelum dilaksanakannya ritual alo.

Berbagai unsur simbolik anti struktur ini bertujuan menciptakan kondisi "awal" atau eksistensial sebagai tahap persiapan di mana proses penyadaran diri para pelaku ritual atau subjek ritual itu akan berlangsung (Winangun, 1990: 35).

\section{Tahap Liminal atau Liminalitas.}

Masa antara peristiwa kematian hingga pelaksanaan ritual alo merupakan masa perkabungan yang ditandai oleh suasana dan aktivitas khusus yang berbeda dari masa sebelumnya. Semua aktivitas harian seperti melaut, membuka lahan perkebunan, berburu, pergi merantau dan sebagainya, yang biasanya dilakukan sebelum masa perkabungan, umumnya tidak boleh dilakukan. Selain berbagai aktivitas tersebut, perkara lain yang pantang dilakukan pada masa ini adalah membagi-bagi harta peninggalan anggota keluarga yang telah meninggal dunia tersebut, seperti tanah ulayat, tabungan, pakaian, perhiasan dan sebagainya. Simbol-simbol berupa bendera putih yang ditancapkan di halaman depan rumah duka dimaksudkan menciptakan kondisi hening bagi anggota kerabat yang ditinggalkan. Semua bentuk aktivitas simbolik itu menandakan diawalinya masa perkabungan.

Sejak saat itu, kaum kerabat yang ditinggalkan menjalani berbagai pantangan sebagaimana telah disebutkan di atas. Di dalam kondisi ini seluruh dari mereka baik perasaan-perasaan maupun aktivitas lainnya tertuju pada pengalaman yang sedang mereka hadapi yakni peristiwa kematian anggota keluarga mereka. Berdasarkan keyakinan mereka, selama masa ini roh orang yang telah meninggal dunia tersebut masih berada bersama-sama dengan mereka. Karena itu suasana ketenangan atau keheningan perlu dipelihara dengan sebaik-baiknya jangan sampai mengundang kemarahan roh tersebut 
dan mendatangkan marabahaya bagi mereka yang melanggarnya.

Di dalam masa perkabungan ini para kerabat melaksanakan beberapa kegiatan, di antaranya mengkhatamkan al Quran (membacakan al Quran 30 juz) beberapa kali untuk melapangkan jalan (kabhembasano lala) bagi roh tersebut menuju tempatnya yang abadi (surga). Mereka yang hadir dalam kegiatan ini umumnya lancar dalam membaca al Quran, sebab kesalahan dalam membaca diyakini berpengaruh terhadap perjalanan roh tersebut. Dengan mengkhatamkan al Quran diharapkan roh anggota keluarga mereka tersebut memperoleh kemudahan dalam perjalanannya ke surga, berupa terhindar dari siksa kubur, diberatkan timbangan amalnya, dan selamat ketika melewati "shirat" (jembatan menuju surga).

Selain aktivitas mengkhatamkan al Quran, aktivitas lain yang juga nampak dilakukan dalam masa ini adalah kunjungan dan perhatian dari berbagai pihak, sanak keluarga atau kerabat, tetangga, kenalan dan sahabat. Meskipun kehadiran mereka tersebut tidak rutin dan hanya sesaat, namun memiliki pengaruh psikologis yang luar biasa bagi kaum kerabat yang sedang berkabung itu. Kunjungan dan perhatian sanak keluarga, tetangga dan sahabat itu membuat mereka merasa terhibur, terbangkitkan, terkuatkan dan terteguhkan. Dalam kunjungan dan pertemuan seperti ini khusus di antara kerabat yang ditinggalkan, diperbincangkan pula mengenai beberapa hal berupa hak waris atas wilayah tanah, tanaman peninggalan, utang-piutang, dan hal-hal lain yang dianggap penting. Namun jika tidak ada peninggalan apa-apa, maka dalam kesempatan ini isi perbincangan lebih berkaitan pewarisan hak tanah ulayat dan persiapan untuk pelaksanaan ritual alo almarhum-almarhumah hingga yang keseratus harinya (ahacu alo) nanti.

Berbagai aktivitas selama masa perkabungan baik mengkhatamkan al Quran, kunjungan sanak keluarga, tetangga, sahabat, dan isi perbincangan menyangkut hak waris tanah ulayat, secara tidak disadari para pelaku itu telah berrefleksi terhadap pengalaman yang tengah mereka hadapi dan diri mereka sendiri. Aktivitas mengkhatamkan al Quran dan perbincangan menyangkut hak waris tanah ulayat, secara tidak langsung telah membeberkan orientasi hidup ke depan yang lebih baik, membangun harapan dan semangat yang baru dalam kehidupan mereka. Turner menyebutnya "proses refleksi formatif".

Melalui proses tersebut terbentuk dalam diri para pelaku ritual pemahaman (kognisi), nilai-nilai (moral) dan semangat hidup yang baru (psikologis spiritual). Pemahaman, moral dan semangat hidup itulah yang kemudian menjadi landasan atau pegangan bagi hidup mereka nanti. Dengan kata lain aktivitas ritual di 
atas dengan berbagai unsur simbolik tersebut memperlihatkan adanya suatu proses dekonstruksi terhadap kondisi hidup yang ada dan sekaligus rekonstruksi huidup yang baru, di mana pandangan dan semangat hidup pelaku ritual itu diperbaharui. Dengan pemahaman dan semangat hidup yang baru, kehidupan dapat berjalan secara normal kembali

Salah satu aspek dalam tahap liminalitas yakni kommunita yakni suatu relasi antar pribadi yang dibentuk oleh adanya pengalaman dan kondisi batin yang sama. Hal ini bukan hanya terjadi di kalangan pelaku ritual itu saja. Kehadiran berbagai pihak baik kaum kerabat, tetangga dan sahabat dalam perbincangan maupun sumbangan material dalam konteks ini membentuk sebuah komunitas. Kehadiran simbolis itu mengungkapkan adanya perasaanperasaan dan pengalaman yang sama dalam peristiwa tersebut. Kebersamaan ini untuk sementara waktu meredam berbagai konflik akibat peristiwa kematian. Pengalaman kematian menjadi pengalaman bersama tidak hanya pengalaman sanak keluarga yang berduka semata.

Menurut para informan, kunjungan dan perhatian sanak keluarga, tetangga dan sahabat itu membuat mereka yang berduka merasa terhibur dan diteguhkan. Beban batin akibat peristiwa kematian itu menjadi ringan. Kesepian dan kedukaan mereka menciptakan suasana kebersamaan yang mendalam di antara mereka. Dengan kata lain, di dalam aktivitas simbolik itulah kaum kerabat alamarhum mendapat peneguhan dan kekuatan secara psikologis maupun spiritual. Berbagai aktivitas selama masa perkabungan di atas merupakan bagian terpenting dari tahap liminal. Melalui berbagai aktivitas dalam kondisi tersebut secara tidak disadari terjadi proses retrospeksi dan introspeksi di dalam diri kaum kerabat almarhum tersebut. Di dalam proses tersebut mereka dihadapkan pada kenyataan yang mereka alami sebagai pengalaman mendasar (eksistensial) yang harus diolah untuk menemukan nilai positif dari pengalaman itu.

Menurut Turner, proses demikian akan menghasilkan perubahan secara kognitif, psikologis dan sisiologis dalam diri pelaku ritual itu. Melalui proses tersebut mereka memperoleh pemahaman, dan pengetahuan hidup yang baru bagi diri mereka. Kematian bukan lagi menjadi akhir dari suatu kehidupan yang mencemaskan dan menakutkan, tetapi bagian dari proses hidup manusia di dunia ini menuju kehidupan yang lebih sempurna di akhirat yaitu surga, tempat semua arwah berkumpul dan rnenikmati ketentrarnan hidup yang purna waktu. Dalam kondisi demikian (psikologis, kognisi dan moral yang baru) para subjek ritual siap menjalani kehidupan di tengah masyarakatnya. 
3. Tahap pengintegrasian kembali atau reaggregation

Pelaksanaan ritual alo (mulai tolu alono, picu alono, pato puluno, hingga ahacu alono), menandai terjadinya proses pengintegrasian kembali (reaggregation) perubahan batin yang diakibatkan peristiwa kematian. Pada saat ritual itu, kaum kerabat orang yang meninggal terbebaskan dari rasa perkabungan. Demikian pula roh kerabat yang meninggal dunia dapat melanjutkan perjalanannya ke syurga dan berkumpul bersama roh kerabat lain yang telah mendahuluinya. Kemeriahan ritual alo khususnya selamatan hari yang ketujuh (picu alono) dan keseratus (ahacu alo) ditandai oleh kehadiran para kerabat, tetangga, sahabat, kenalan, suasana riang dan makan bersama. Sejak saat itu mereka boleh melakukan aktivitas harian dengan bebas seperti tertawa, menyanyi, mendengarkan musik dan sejenisnya yang tidak boleh dilakukan selama masa perkabungan. Demikian pula kegiatan mencari nafkah untuk kebutuhan hidup sehari-hari seperti melaut, membuka lahan perkebunan, berburu, pergi merantau, menjual ke pasar dan sebagainya, mulai diperbolehkan. Pada masa ini, seluruh harta dan barang peninggalan kerabat yang telah meninggal dunia seperti tanah ulayat, tanaman, tabungan, pakaian, perhiasan, dan sebagainya, sudah diperbolehkan untuk dibagi-bagi oleh segenap kaum kerabat yang masih hidup.

Uraian ini memperlihatkan bahwa ritual alo memiliki mekanisme pengolahan batin yang berjalan secara bertahap. Menurut hemat penulis tahapan ini berhubungan dengan apa yang dimaksudkan Turner dengan tahapan separation, liminal dan reaggregation. Melalui proses pelaksanaan ritual ini, berbagai konflik dan ketegangan batin yang dialami kaum kerabat yang ditinggalkan diakomodir. Hasil dari proses tersebut ialah konflik dan ketegangan hidup diredam dan sekaligus tercipta orientasi hidup yang baru bagi para pelaku ritual tersebut.

Dengan demikian dapat dikatakan bahwa ritual alo, sesungguhnya bermakna produktif dan sekaligus konstruktif. Makna produktif nampak dari mekanisme pengolahan batin/psikologis yang dijalani para pelaku ritual selama masa perkabungan. Berbagai unsur simbolik yang digunakan di dalam ritual tersebut menjadi media yang mengakomodir proses tersebut. Makna konstruktif dari ritual tersebut ialah hasil yang dicapai dari mekanisme tersebut. Melalui pelaksanaan ritual, kondisi batin pelaku ritual yang mengalami krisis akibat kematian seperti lesu, kalut, linglung, putus asah dan tidak memiliki masa depan dihidupkan kembali. Proses tersebut menghantar para pelaku ritual tersebut kepada suatu orientasi hidup yang baru dan menumbuhkan 
semangat hidup dalam diri mereka. Adanya orientasi dan semangat hidup baru dalam diri para pelaku ritual membuat mereka siap untuk menerima dan menjalani kehidupan harian dengan mantap tanpa adanya kekawatiran atau kecemasan lagi.

\section{Simpulan}

Berdasarkan uraian di atas, dapat ditarik sebuah kesimpulan bahwa ritual alo dilaksanakan dengan maksud agar berbagai konflik dan ketegangan batin dan pikiran yang dialami kaum kerabat yang ditinggalkan akibat peristiwa kematian dapat terakomodir (terhibur, terbangkitkan, terkuatkan dan terteguhkan, baik secara psikologis maupun spritual), sekaligus tercipta orientasi hidup yang baru tanpa adanya kekhawatiran dan kecemasan lagi. Dengan demikian dapat dikatakan bahwa ritual alo, sesungguhnya bermakna produktif dan sekaligus konstruktif. Selain itu, ritual tersebut dapat pula dikatakan sebagai bagian vital dari unsur kebudayaan masyarakat Cia-Cia Burangasi yang setidak-tidaknya hingga kini dianggap masih memadai mengakomodir berbagai krisis batin akibat adanya perubahan-perubahan yang mengitari tahapan hidup manusia, khususnya yang diakibatkan oleh peristiwa kematian.

\section{Daftar Pustaka}

Bungin, Burhan. 2007. Penelitian Kualitatif: Komunikasi, Ekonomi, Kebijakan Publik, dan Ilmu Sosial Lainnya. Jakarta: Kencana.

Koentjaraningrat. 1980. Sejarah Teori Antropologi. Jakarta: UI Press Jilid I.

Koentjaraningrat. 1993. Kebudayaan dan Agama (cetakan kedua). Yogyakarta: Kanisius.

Spradley, James, P. 1997. Metode Etnografi. Yogyakarta: Tiara Wacana.

Turner, Victor. 1967. The Forest of Symbols Aspecs of Ndembu Ritual. London: Cornell Paperback. Cornell University Press.

Turner, Victor. 1982. The Forest of Symbols, Aspects Of Ndembu Ritual. Ithaca and London. Sixth Printing: Cornell University Press.

Winangun, Wartaya. 1990. Masyarakat Bebas Struktur, Liminalitas dan Komunitas Menurut Turner. Yogyakarta: Kanisius. 